\title{
Pengaruh Industri Batubara Terhadap Polusi Udara dalam Keseimbangan World Air Quality Index in India
}

\section{The Effect of Coal Industry on Air Pollution in Balance of the World Air Quality Index in India}

\author{
Krisma Trianisa*, Eko Priyo Purnomo, Aulia Nur Kasiwi \\ Department of Government Affairs and Administration, Jusuf Kalla School of \\ Government, Universitas Muhammadiyah Yogyakarta, Indonesia \\ *corresponding author, email: sutiknoris@gmail.com
}

Manuscript received: 11-05-2020. Accepted: 18-06-2020

\begin{abstract}
ABSTRAK
Penelitian dilakukan atas keingintahuan peneliti akan berbagai permasalahan lingkungan yang muncul sebagai akibat dari kondisi bumi yang tak mampu lagi menopang segala kebutuhan dan keinginan manusia yang tak terhingga. Namun untuk menghindari terlalu luasnya bahasan, penelitian akan berfokus pada bagaimana peran serta batubara dalam menyumbang tingginya tingkat polusi udara di India. Polusi udara merupakan salah satu masalah lingkungan yang sering mendapatkan perhatian dunia. Berbicara tentang polusi udara pastilah sangat erat kaitannya dengan Negara India yang posisinya sebagai negara dengan tingkat polusi terparah di dunia. Metode dalam penelitian ini menggunakan jenis metode kualitatif dengan sumber data berupa kajian pustaka yaitu artikel jurnal yang memiliki keterkaitan dengan topik penelitian. Data-data yang didapat melalui kajian pustaka selanjutnya akan dilakukakan analisis data dengan tahap reduksi data, penyajian data dan penarikan kesimpulan. Berdasarkan hasil penelitian dapat diketahui bahwa batubara merupakan bahan bakar primadona yang digunakan oleh India sebagai penopang besarnya kebutuhan energi masyarakat India. Memang sumber daya alam batubara ini membawa dampak positif bagi keadaan ekonomi dan kondisi ketahanan energi di India namun ada hal yang lebih urgent yang perlu mendapatkan perhatian yaitu dampak negatif penggunaan batubara berupa polusi yang justru sangat berbahaya bagi kelangsungan hidup masyarakat India. Maka dari itu, untuk melindungi masyarakat dari semakin buruknya kondisi udara di India dibutuhkan upaya serius dari berbagai kalangan, khususnya pemerintah.
\end{abstract}

Kata kunci : dampak; energi; lingkungan; positif; polusi;

\section{ABSTRACT}

The research was conducted on the researcher's curiosity on various environmental problems that arise as a result of the condition of the earth that is no longer able to sustain all the needs and desires of humans are infinite. But to avoid too much discussion, research will focus on how coal's role in contributing to high levels of air pollution in India. Air pollution is one of the environmental 
problems that often gets the world's attention. Talking about air pollution must be very closely related to the State of India, whose position as the country with the worst levels of pollution in the world. The method in this study uses a type of qualitative method with the source of data in the form of a literature review that is journal articles that have relevance to the research topic. The data obtained through the literature review will then be carried out data analysis with data reduction stages, data presentation and drawing conclusions. Based on the results of the study it can be seen that coal is the belle of fuel used by India as a support for the large energy needs of Indian society. Indeed, coal's natural resources have a positive impact on the economic situation and conditions of energy security in India, but there are more urgent things that need attention that is related to the negative impact of coal use in the form of pollution which is very dangerous for the survival of Indian society. Therefore, to protect the public from the worsening air conditions in India requires serious efforts from various groups, especially the government.

Keywords: energy; environment; positive; pollution

\section{PENDAHULUAN}

Pertumbuhan ekonomi merupakan suatu hal yang menjadi idaman bagi negaranegara didunia. Bahkan berbagai upaya dilakukan oleh berbagai negara untuk mencapai pertumbuhan ekonomi setinggi-tingginya. Namun seringkali manusia tidak menyadari atau bahkan melalaikan bahwa sesungguhnya bumi yang dipijak ini memiliki batasan tertentu untuk menampung dan memenuhi berbagai keinginan manusia sebagai penghuni bumi. Perilaku manusia untuk memenuhi kebutuhan dan keinginannya seringkali melintasi batas daya dukung atau kemampuan bumi yang pada akhirnya akan mengancam alam dan bahkan kelangsungan hidup populasi manusia sendiri di masa depan. Ketika manusia melanggar batas-batas planet, yang berarti bahwa tekanan manusia terhadap lingkungan menjadi lebih besar dari kemampuan sistem alami bumi untuk menyerap tekanan manusia, maka hasilnya adalah perubahan besar dalam fungsi ekosistem bumi. Perubahan-perubahan tersebut pada gilirannya juga akan mengancam kesejahteraan manusia dan bahkan kelangsungan hidup manusia (Sachs, 2015).

Perubahan iklim, pengasaman laut, penipisan lapisan ozon hingga polusi merupakan bentuk ketidakmampuan bumi terhadap tekanan kebutuhan manusia yang tiada batas. Kebutuhan manusia yang selalu meningkat ini juga diperparah dengan jumlah populasi manusia yang semakin lama semakin tidak terkendali sehingga bumi tidak mampu menopang semuanya. Bahkan salah satu bentuk ketidakmampuan bumi yaitu polusi menjadi suatu masalah besar sehingga mendapat perhatian dunia hingga saat ini. Salah satu jenis polusi yaitu polusi udara dinilai telah menyumbang lebih tinggi angka kematian dibandingkan asap rokok. Berdasarkan penelitian yang dipimpin oleh ilmuan dari Max Planck Institute for Chemistry diketahui bahwa polusi udara berperan sebagai penyebab utama sembilan juta kelahiran secara prematur setiap tahunnya, besarnya angka tersebut dua kali lipat dari yang diperkirakan. Pencemaran udara juga memegang tanggung jawab besar atas kasus 8,8 juta kematian yang ada didunia. Sistem pernapasan, kinerja jantung dan juga sirkulasi darah merupakan sasaran utama polusi udara yang akan dilemahkan kinerjanya. Dampak dari partikel kecil polutan yaitu PM 2.5 yang dapat menembus ke dalam sistem pernapasan dan juga paru-paru kebanyakan bersumber dari pembakaran kayu, knalpot 
kendaraan, produksi industri dan pastinya bahan bakar fosil (Widyaningrum, 2019). Kesehatan merupakan ancaman terbesar dari kualitas udara yang buruk akibat berbagai kandungan polutan diudara.

Berbicara tentang polusi, India merupakan negara yang sangat sering dikaitkan dengan pembahasan mengenai polusi apalagi dalam hal polusi udara. Berdasarkan data dari CNN Indonesia, daftar kota dengan polusi terburuk dunia pada tahun 2018 sebagian besar ada di India. Pada posisi 10 teratas, 7 kota di India dengan total keseluruhan kota di India yaitu 10 kota masuk dalam kategori wilayah dengan kualitas udara terburuk di dunia. Sementara tiga kota lainnya dengan kualitas udara terburuk di dunia dipegang oleh Cina. Namun disisi lain, terdapat hasil penelitian yang menunjukkan India merupakan salah satu negara dengan pertumbuhan ekonomi terpesat didunia (CNNIndonesia, 2019). Maka dari itu muncul keingintahuan dari penulis untuk meneliti bagaimana pengaruh faktor ekonomi sehingga menjadikan India menjadi negara dengan kualitas udara terburuk dunia? Namun peneliti akan membatasi pembahasan dalam mengkaji faktor tingginya polusi udara di India yaitu dalam aspek masifnya penggunaan batubara sehingga menyebabkan buruknya kondisi udara di India. Penelitian melalui kajian pustaka ini dilakukan dengan harapan dapat memberikan kemanfaatan sebagai bahan edukasi negara lain, khususnya bagi Negara Indonesia. Beberapa wilayah di Indonesia terutama Ibu Kota Jakarta seringkali memiliki kualitas udara dibawah kata layak untuk sistem pernapasan dengan jumlah standar konsentrasi udara jauh melebihi standar yang telah ditetapkan WHO (World Health Organization). Maka dari itu, kajian mengenai tingginya polusi di India ini perlu dilakukan agar dapat dijadikan rujukan bagi Indonesia untuk terhindar dari kualitas udara yang semakin memburuk untuk kedepannya.

\section{Polusi di Indonesia}

Berbicara tentang polusi, Jakarta merupakan salah satu kota yang memiliki kondisi udara yang mengkhawatirkan bahkan dapat digolongkan sangat berbahaya. Menurut penelitian Greenpeace, kondisi tersebut disebabkan oleh adanya pembangkit listrik tenaga batubara (PLTU) sebagai faktor yang ikut andil dalam masalah polusi di Jakarta. PLTU merasa bebas karena lemahnya peraturan dan penerapan standar emisi untuk polutan utama yang ditandai dengan diperbolehkanya PLTU di Indonesia untuk mengeluarkan emisi SO2 yang sangat tinggi jika dibandingkan dengan Cina dan juga India (Ruhiat, et al., 2019). Selain akibat PLTU, penelitian yang dilakukan oleh Santoso, dkk. menunjukkan bahwa Jakarta dan juga Semarang merupakan contoh daerah yang terdampak polusi udara akibat adanya pertumbuhan ekonomi dari kegiatan industri. Penelitian pada kedua daerah tersebut menunjukkan adanya korelasi antara parameter ekonomi yaitu variabel Produk Domestik Regional Bruto (PDRB) dengan Aerosol Optical Thickness (AOT) sebagai parameter polusi. Dimana kawasan industri di DKI Jakarta mengalami ekspansi secara spasial dan Semarang dengan perluasan kawasan industri yang cukup cepat (Santoso, et al., 2018).

\section{Polusi di India}

Penelitian yang dilakukan oleh Suharsono dkk. dan juga Bhave \& Shrestha menunjukkan bahwa tak hanya Jakarta, batubara juga menjadi masalah besar bagi India, dimana penggunaan bahan bakar fosil dan biomassa menjadi faktor utama India menjadi 
salah satu negara dengan polusi terparah didunia. Batubara menduduki sumber energi dominan secara nasional di India dalam total campuran energi primer sebesar 56,3 persen yang selanjutnya diikuti minyak dan gas alam. Masyarakat sipil telah mengambil peran lebih aktif dengan menekan pemerintah untuk bertindak salah satunya dengan memperketat standar emisi pembangkit batubara untuk meningkatkan kualitas udara (Suharsono, et al., 2019) (Bhave \& Shrestha, 2020). Selain penggunaan bahan bakar batubara secara masif di India, pembakaran lahan pertanian juga menjadi faktor penyebab kota Delhi, India mejadi kota dengan kondisi udara yang buruk dan mengkhawatirkan. Sebagian besar petani di India telah menggunakan teknik pemanenan gabungan mekanis agar terciptanya suatu efisiensi. Teknik panen tersebut akan menyisakan residu tanaman berlimpah di ladang, yang biasanya dibakar petani untuk menyiapkan ladang mereka untuk penanaman berikutnya. Meskipun secara resmi dilarang secara nasional dan ditegakkan dalam Undang-Undang Pengadilan Hijau Nasional 2010, praktik pembakaran tetap dilakukan oleh petani setelah panen karena dinilai murah dan merupakan cara termudah (Cusworth, et al., 2018).

Penelitian pada sektor pertanian di India juga dilakukan oleh Kumar dkk. yang juga menunjukkan adanya bukti bahwa pertanian menyumbang angka polusi diIndia. Namun dalam penelitiannya lebih mengkaji mengenai polusi tanah pada lahan pertanian, bukan dari sisi polusi udara. Dimana polusi disebabkan oleh pestisida yang digunakan secara luas dan tidak diatur, serta ketersediaannya yang mudah telah menyebabkan ancaman besar bagi lingkungan dan juga kesehatan masyarakat India (Kumar, et al., 2016). India juga merupakan negara dengan pertumbuhan kendaraan yang spektakuler. Hal tersebut sangatlah jelas menjadi faktor lain kondisi udara India semakin memburuk. Zat-zat kimia hasil pembakaran bahan bakar pada kendaraan seperti karbon monoksida, hidrokarbon, nitrogen oksida dll akan menjadi polutan yang membawa dampak buruk bagi kesehatan. Maka dari itu perlu regulasi yang lebih diperketat dan tak hanya memunculkan regulasi melainkan juga diperlukan tumbuhnya kesadaran pada masyarakat (Soni, 2007).

Telah disampaikan sebelumnya bahwa polusi di India merupakan dampak dari penggunaan kendaraan yang meningkat, selain itu adapula faktor lain yang menyumbang polutan di India yaitu aktivitas industri-industri, kelebihan populasi, penggunaan bahan bakar fosil dan proyek pembangunan. Sesungguhnya Mahkamah Agung India secara aktif terlibat dalam mengembangkan, menafsirkan, dan menerapkan perubahan baru dalam Yurisprudensi lingkungan. Namun penegakan instrumen kebijakan dan kesadaran akan pentingnya menjaga lingkungan merupakan hal yang justru perlu ditingkatkan di India (Jain, et al., 2019). Sedangkan, penelitian yang dilakukan oleh Tandon lebih memfokuskan pada permasalahan India untuk mewujudkan suatu pembangunan berkelanjutan yaitu permasalahan pertumbuhan populasi yang sangat tinggi. Meskipun ada konsensus nasional bahwa peningkatan luar biasa dalam populasi negara harus dibatasi, namun sayangnya tidak ada hukum khusus di India yang secara langsung mengatur pertumbuhan populasi (Tandon, 2008). 


\section{Dampak polusi}

Menurut penelitian yang dilakukan oleh Yusad, polutan yang timbul dari kendaraan bermotor dan aktifitas pabrik-pabrik industri seperti proses pembakaran dan pembuangan limbah merupakan hal yang sangat berbahaya bagi kesehatan masyarakat. Dampak utama pada gangguan kesehatan yaitu pada sistem pernapasan, persyarafan, hati, pembuluh darah dan ginjal (Yusad, 2003). Salah satu kasus polutan yang membawa masalah kesehatan yaitu dapat dilihat dari dampak pencemaran udara terhadap kesehatan pernafasan pada penduduk daerah penambangan batubara di Odisha, India. Sebagian besar masyarakat yang bermukim di daerah penambangan batubara Odisha memiliki masalah pada kesehatan paru-paru dan dada, batuk, asma bronkial, bronkitis, TB dan penyakit terkait paru lainnya (Nayak \& Chowdhury, 2018). Bahkan residu organofosfat yang merupakan zat kimia sintetis pada pestisida yang digunakan secara masif di India dan menjadi salah satu polutan juga telah ditemukan dalam darah, urin, ASI masyarakat India akibat penggunaan pestisida yang berlebihan dan hal tersebut dapat pula berakibat pada kematian (Kumar, et al., 2016). Selain dari sisi kesehatan, zat-zat polutan juga menyebabkan terjadinya pemanasan global. Pemanasan global telah membawa dampak pada penurunan hasil panen gandum di India. Hasil penelitian yang dilakukan oleh Gupta dkk. menunjukkan bahwa pemanasan global selama periode 1981-2009 telah mengurangi hasil gandum di India sekitar 5,2 persen dan juga diperkirakan akan terjadi penurunan hasil panen sebesar 5,9\% persen setiap peningkatan suhu sebesar $1^{\circ} \mathrm{C}$ (Gupta, et al., 2017).

\section{Upaya penanganan polusi}

Untuk menangani segala permasalahan polusi tersebut perlu dilakukan upaya-upaya oleh berbagai pihak. Greenpeace sebagai salah satu NGO Lingkungan menggunakan strategi undertaking research dan campaigning \& organizing public protest untuk membantu mengatasi masalah polusi di Jakarta. Strategi undertaking research diterapkan dengan cara melakukan penelitian atau kajian yang berfokus pada masalah polusi di Jakarta agar memperoleh data yang pada akhirnya digunakan untuk mempengaruhi keluarnya kebijakan pemerintah. Selanjutnya strategi campaigning \& organizing public protest dilakukan Greenpeace dengan melakukan aksi kampanye dan merangkul masyarakat yang dirasa memiliki visi misi yang sama untuk mem-blowup isu yang sedang diperjuangkan (Ruhiat, et al., 2019).

Berbeda halnya dengan cara penyelesaian permasalahan polusi lintas batas antara Tiongkok dan Korea Selatan yang memilih melalui diplomasi publik dengan membentuk berbagai kerja sama bilateral dan juga multilateral yang melibatkan negara - negara lain di Asia Timur. Polusi yang menyebar hingga ke Korea Selatan disebabkan oleh proses produksi yang dilakukan secara besar-besaran oleh Cina. Motif Korea Selatan tidak melakukan protes keras secara langsung ke Tiongkok yaitu karena adanya faktor ekonomi yang tak ingin hakhak istimewanya dalam perdagangan dicabut (Rezqi, 2016). Memang pada dasarnya ada keterkaitan bidang atau kegiatan ekonomi dengan terciptanya polusi. Seperti hasil penelitian yang dilakukan Alfisyahri menunjukkan Produk Domestik Bruto mempunyai kausalitas terhadap penggunaan atau konsumsi energi hydropower. Begitupula dengan penggunaan 
energi hydropower yang memiliki hubungan sebab akibat terhadap tingkat emisi karbon dioksida di Negara-negara G20 salah satunya India. Sehingga kebijakan dan kesepakatan mengurangi tingkat penggunaan energi tidak terbarukan dan pengurangan emisi pada hasil perjanjian-perjanjian yang dilakukan akan memiliki sebab akibat yang berbeda setiap Negara (Alfisyahri, et al., 2020).

Selain melalui kerjasama untuk mengatasi masalah polusi, muncul pula upaya pemantauan kadar atau kualitas udara disuatu wilayah yang diharapkan dapat berkontribusi dalam pengurangan masalah polusi. Dalam perkembangan era digital seperti saat ini mendorong munculnya teknologi pemantauan udara yang menjadi konsep penting untuk memeriksa apakah udara sekitar kita layak untuk sistem pernapasan. Teknologi ini didasarkan pada konverter mikro sensor pintar suatu aplikasi dengan bantuan jaringan yang mengunduh level polutan untuk menyampaikan informasi pada komputer untuk diproses lebih lanjut. Kamera web pengawasan resolusi tinggi akan digunakan untuk memantau kualitas udara melalui internet (Sirsikar \& Karemore, 2015).

\section{BAHAN DAN METODE}

Metode penelitian ini menggunakan analisis kualitatif, yang bertujuan untuk menafsirkan suatu keadaan, fakta dan fenomena yang terjadi dengan didukung oleh dokumentasi dan studi terdahulu untuk memberikan penguatan dalam subjektivitas serta objektivitas suatu permasalahan. Data pendukung pada makalah ini oleh data kualitas udara yang tersedia dan dapat diakses dalam Index Air Quality Index (merujuk pada iaqi.com) untuk mengumpulkan data kualitas udara sebagai penguat temuan dalam penelitian ini. Metode penelitian ini didukung dengan kajian literatur yang relevan pada penulisan ini dengan didukung data index pollution yang telah disajikan oleh Organisasi World Air Quallity Index. Jenis penelitian yang digunakan dalam penelitian ini adalah jenis penelitian deskriptif, karena peneliti bertujuan mendapatkan gambaran segala sesuatu yang terkait pengaruh batubara terhadap tingginya angka polusi di India melalui literatur review berupa jurnal yang memiliki ketekaitan dengan terjadinya polusi di India. Literatur review yang penulis gunakan melalui studi pustaka terhadap beberapa jurnal terbagi atas beberapa kelompok bahasan yaitu polusi di Indonesia, polusi di India, dampak polusi dan upaya penanganan polusi.

Penelitian ini juga didukung oleh data kualitas udara yang tersedia untuk umum yang disediakan oleh Indeks Polusi Udara Dunia: Indeks Kualitas Udara Real Time (proyek WAQI) yang mengumpulkan data kualitas udara yang dikumpulkan dari >12.000 stasiun pemantauan kualitas udara berbasis darat. Harus dicatat bahwa data dari WAQI berasal dari stasiun yang dikelola oleh lambaga pemerintah atau lembaga di negara masinh-masing dan mungkin tidak selalu sepenuhnya divalidasi. Penulis menggunakan konsentrasi polutan udara harian yang dikumpulkan dari beberapa stasiun WAQI dimana tersedia untuk analisis lebih lanjut. Berdasarkan indeks kualitas udara yang dirilis melalui AQI di Kota New Delhi tingkat PM adalah 2,553 mikrogram per meter kubik rata-rata. AQI adalah standar keselamatan umum yang terkait dengan standar tingkat polusi udara yang digunakan oleh beberapa negara besar, terutama India (Kasiwi \& Nurmandi, 2018). 


\section{HASIL DAN PEMBAHASAN}

Era globalisasi sangat erat kaitannya dengan kebutuhan energi. Energi menjadi salah satu komoditi utama sebagai kebutuhan primer dalam kehidupan masyarakat, selain itu energi juga digunakan sebagai salah satu penyokong dalam dunia transportasi dan juga industri (Marianta, 2012). Kementerian Energi dan Sumber Daya Mineral Republik Indonesia menyebutkan bahwa kebutuhan akan energi di dunia terus meningkat. Selain itu Badan Energi Dunia (International Energy Agency-IEA) juga memproyeksikan bahwa hingga tahun 2030 permintaan energi dunia akan terus mengalami peningkatan hingga 45 persen atau dapat pula dikatakan akan mengalami kenaikan rata-rata pertahun sebesar 1,6 persen (esdm.go.id, 2008). India juga menjadi salah satu negara dengan kebutuhan energi yang terus mengalami peningkatan setiap tahunnya. Peningkatan kebutuhan energi di India tersebut dipengaruhi oleh salah satu faktor yaitu jumlah penduduk India yang sangat besar dan selalu mengalami peningkatan.

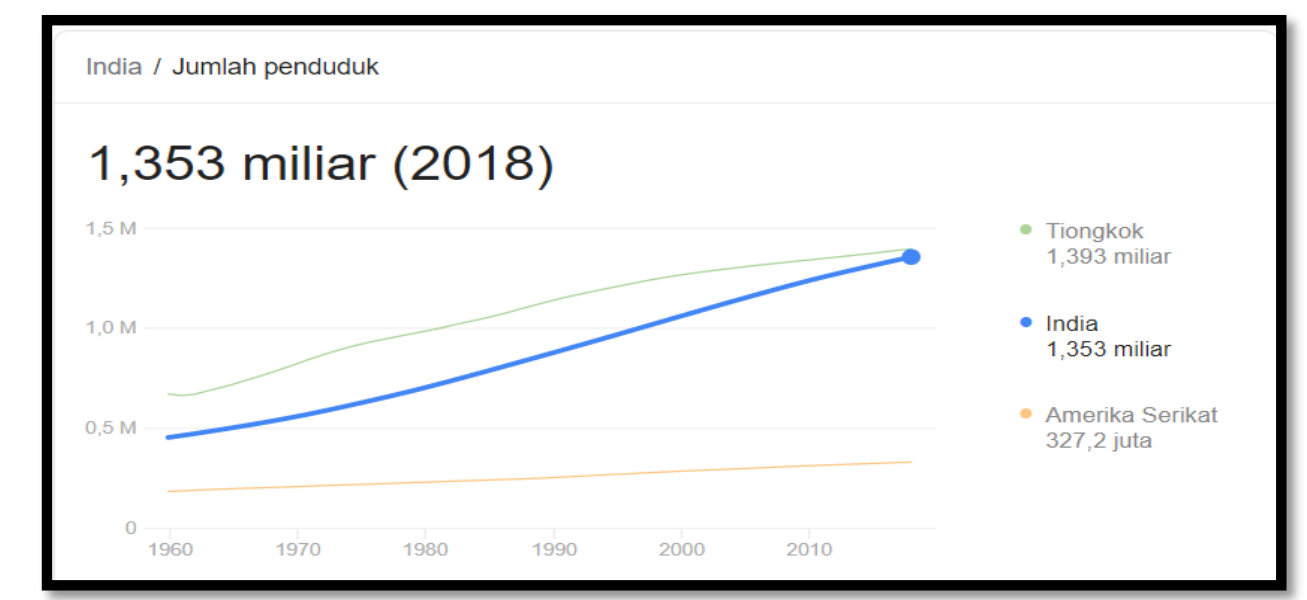

Sumber: Wikipedia yang bersumber dari Bank Dunia dan Biro Sensus Amerika Serikat

Jumlah penduduk India yang selalu mengalami peningkatan akan secara otomatis berdampak pada semakin besarnya jumlah ketersediaan energi yang harus disediakan agar kehidupan masyarakat tidak terganggu. Dominasi atau sekitar 80 persen kebutuhan energi dunia dipenuhi dengan penggunaan bahan bakar fosil (esdm.go.id, 2008). Salah satu bahan bakar fosil yang menjadi pilihan utama dunia sebagai bahan bakar pembangkit energi listrik yaitu batubara. Pemilihan batubara sebagai andalan bahan baku pembangkit listrik tidak terlepas dari alasan bahwa ketersediaan bahan bakar fosil ini sangat melimpah dan harganya dapat dikatakan terjangkau. Maka dari itu, tak heran jika India dalam memenuhi kebutuhannya akan energi sebagai negara yang memiliki jumlah masyarakat yang besar memilih batubara sebagai bahan bakar utama dalam pembangkit energi listrik. Tingginya angka penggunaan batubara oleh India tersebut nampak pada posisi India yang menempati rangking ke tiga dunia dalam hal konsumsi batubara yang bersumber dari data United States Energy Information Administration (indexmundi.com, 2020). 


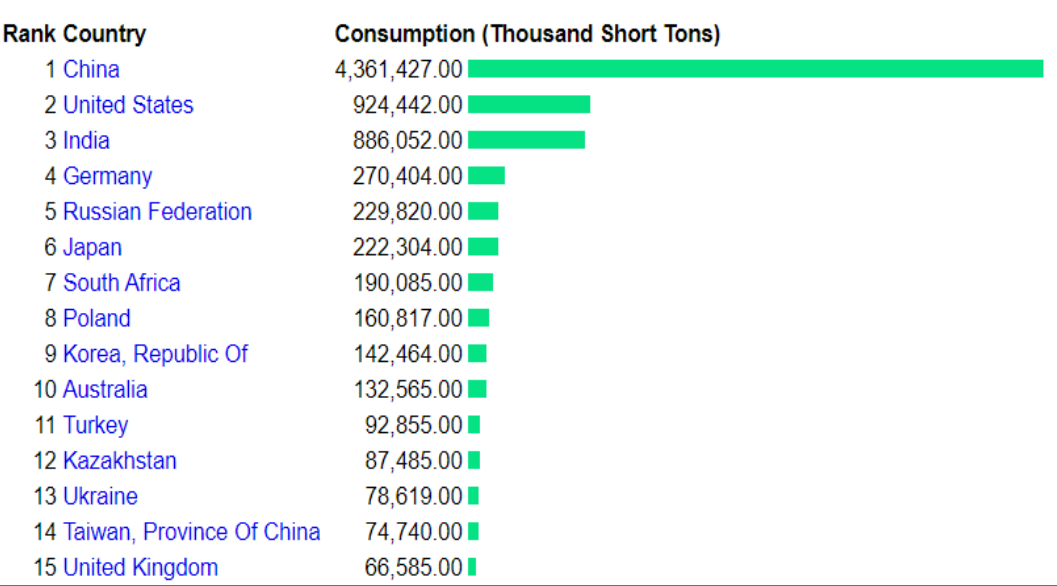

Gambar 2. Coal Consumption by Country

Sumber: United States Energy Information Administration publish by indexmundi.com

Batubara merupakan bahan bakar utama yang digunakan sebagai pembangkit dalam Pembangkit Listrik Tenaga Uap (PLTU). Pemanasan air pada boiler yang dimana proses tersebut menggunakan batubara akan menghasilkan uap air dengan tekanan tertentu yang digunakan untuk menggerakkan turbin melalui suatu proses pembakaran. Dari proses pembakaran pada boiler tersebut akan dihasilkan sisa pembakaran batubara yang berupa debu atau gas asap yang dibuang lepas ke udara sehingga mampu mengakibatkan terjadinya polusi udara. Apabila kadar polutan atau pencemaran udara terlalu tinggi di lingkungan maka kondisi tersebut akan membahayakan kelangsungan hidup makhluk hidup yang ada dilingkungan tersebut (Palit, et al., 2017). Penggunaan batu bara secara masif sebagai pembangkit listrik di India terbukti menghasilkan berbagai biaya eksternal, termasuk polusi udara. Health Effects Institute (2018) menyatakan bahwa batubara merupakan salah satu sumber terbesar partikel halus (PM2.5) di India saat ini, dan akan menjadi sumber tunggal terbesar pada tahun 2050, yang bertanggung jawab atas 1,3 juta kematian per tahun. Batubara juga merupakan sumber tunggal terbesar dari emisi gas rumah kaca yang mendorong perubahan iklim (Health Effects Institute, 2018) dalam (Suharsono, et al., 2019).

Tak hanya penggunaan atau konsumsi batubara yang mendorong India menjadi negara dengan polusi udara tinggi, India juga menjadi negara produsen batubara terbesar ketiga didunia yang bersumber dari data United States Energy Information Administration (indexmundi.com, 2020). Proses penambangan batubara yang dilakukan secara besarbesaran berdampak pada posisi India sebagai produsen besar batubara dunia yang juga tak terlepas karena fakta kondisi negara tersebut memiliki kebutuhannya akan bahan baku primadona tersebut sebagai pembangkit listrik untuk kebutuhan warganya dan untuk menopang berbagai sektor ekonomi lainnya. Penambangan batubara merupakan suatu pekerjaan yang dapat dikatakan memiliki tingkat kesulitan tinggi dan rentan terjadinya cidera dan penyakit. Penyakit yang berkaitan dengan pernapasan akibat debu dari aktifitas penambangan batubara merupakan masalah besar yang dihadapi masyarakat yang tinggal disekitar kawasan penambangan. Bahan galian mineral dari hasil penambangan perlu dilakukan pemrosesan selanjutnya salah satunya proses pemisahan material pengikut yang 
tidak digunakan. Proses pemisahan mineral yang tidak digunakan atau diperlukan tersebut akan berposisi sebagai limbah dalam industri pertambangan dan juga yang lebih parahnya lagi akan menjadi bahan pencemaran lingkungan (Mursyidin \& Warnida, 2016).

Pemanfaatan tambang batubara merupakan suatu pemanfaatan sumber daya alam yang membawa keuntungan bagi pembangunan energi dan juga perkenomian, namun tak dapat dipungkiri pula aktifitas penambangan batubara sangat erat kaitannya akan akibat pencemaran lingkungan. Maka dari itu, tak heran jika India yang merupakan negara terbesar ketiga didunia dalam hal produsen sekaligus konsumen batubara juga menduduki posisi sebagai salah satu negara dengan kualitas udara yang terburuk didunia, dimana 7 kota di India dengan total keseluruhan kota di India yaitu 10 kota masuk dalam kategori 10 wilayah dengan kualitas udara terburuk di dunia (CNNIndonesia, 2019). Kerusakan lingkungan salah satunya akibat proses produksi batubara dimulai dari kegiatan membuka lahan dan juga kegiatan-kegiatan lain seperti pengambilan batubara, pengangkutan, proses penyimpanan sementara dan hingga batubara tersebut dibakar. Penebangan hutan saat pembukaan lahan untuk lokasi penambangan batubara dapat menyebabkan kerusakan lingkungan atau ekosistem. Menurut Purnomo dan Suhendri, dalam proses alih fungsi hutan dan pembukaan hutan, seringkali masyarakat lebih memilih dengan cara membakar lahan karena dirasa merupakan cara yang lebih murah dibandingkan dengan cara lain yang tidak merusak lingkungan, sehingga dalam proses pembukaan lahan tak terhindarkan dari penciptaan polusi di udara (Purnomo \& Suhendri, 2017). Selain itu, dalam penelitian yang lain Purnomo, dkk juga menjelaskan bahwa pada dasarnya pembukaan lahan dengan cara membakar hutan merupakan metode umum yang sering digunakan petani kecil, lahan yang dibakar tersebut selanjutnya dijual demi memperoleh keuntungan. Elit lokal yang membeli lahan dari petani kecil tersebut akan mendapat manfaat dari transformasi tanah ini, namun pada dasarnya sebernarnya petani kecil berada pada posisi yang kurang menguntungkan secara ekonomi (Purnomo, et al., 2019).

Kegiatan yang dapat merusak lingkungan akibat aktivitas penambangan batubara juga terjadi saat pengambilan atau exploitasi batubara dimana membawa dampak pada pencemaran udara akibat partikel debu batubara, bahkan dapat menyebabkan terjadinya erosi, pencemaran logam-logam berat, pendangkalan sungai hingga terbentuknya air asam tambang (AAT). Untuk proses penyimpanan sementara batubara dapat juga memicu terjadinya pencemaran atau polusi udara, air dan juga tanah. Sedangkan saat proses pembakaran batubara yang digunakan sebagai sumber energi menyebabkan lepasnya emisi zat berbahaya ke udara yang berupa $\mathrm{CO}, \mathrm{As}$, Se, $\mathrm{Hg}$ dan gas Nox, CO2 dan SO2. Kondisi semacam ini akan membawa dampak kerusakan lingkungan dan dapat pula membahayakan kesehatan (Setiawan, et al., 2018). 


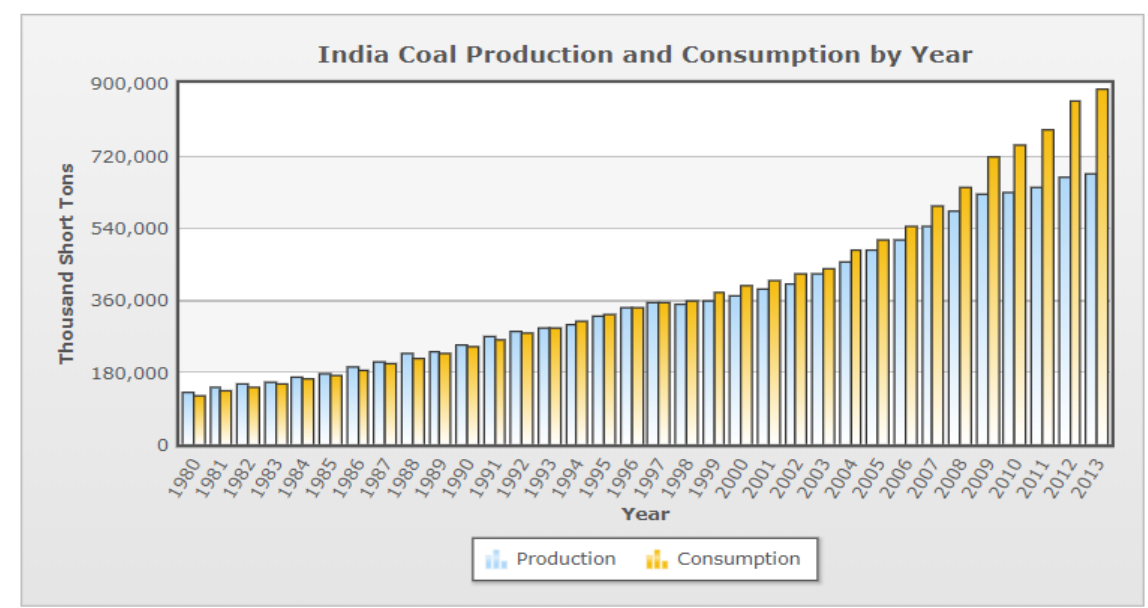

Gambar 3. India coal production and consumption by year

Sumber: United States Energy Information Administration publish by indexmundi.com

Meskipun India telah melakukan exploitasi batubara secara besar-besaran, namun hasil penambangan yang dilakukan negara tersebut akhir-akhir ini tak mampu memenuhi seluruh jumlah kebutuhan konsumsi yang digunakan negaranya sendiri, sehingga India harus melakukan impor batubara dari negara lain. Maka dari itu, dapat dibayangkan bagaimana buruknya kualitas udara India sebagai negara konsumtif akan batubara untuk memenuhi kebutuhan energi masyarakatnya. Tak heran pula jika berdasarkan data dari Global Alliance on Helath and Pollution (GAHP), India menempati urutan pertama sebagai negara dengan angka kematian tertinggi akibat polusi. GAHP juga melaporkan bahwa polusi merupakan salah satu penyebab utama kematian prematur di dunia yaitu sekitar 15 persen atau 8,3 juta orang meninggal. Kematian akibat polusi dipimpin oleh India dengan jumlah sekitar 2,3 juta dan selanjutnya disusul oleh Cina dengan 1,8 juta kematian (republika.co.id, 2019). Kematian yang salah satunya disebabkan oleh aktifitas penggunaan batubara secara masif di India terjadi ketika terciptanya polusi udara saat batubara dibakar sebagai bahan bakar untuk pembangkit listrik. Batubara menghasilkan sejumlah emisi yang membawa efek terhadap lingkungan, termasuk $\mathrm{CO}, \mathrm{CO} 2, \mathrm{NOx}$, dan SOx. Emisi $\mathrm{CO}$ menyebabkan penipisan lapisan ozon (O3) yang dapat menyebabkan kanker kulit, selain itu emisi $\mathrm{CO}$ yang dihirup oleh manusia menyebabkan berkurangnya oksigen pada aliran darah sehingga dapat menyebabkan kematian (Setiawan, et al., 2018).

Untuk mengatasi dan mencegah semakin buruknya kualitas udara di India, perlu dilakukan beberapa upaya dari berbagai kalangan. Upaya serius perlu digalakkan mengingat keselamatan masyarakat India menjadi taruhan atas keinginan untuk meraih kemajuan ekonomi. Pemerintah merupakan pihak yang sangat strategis dalam mengupayakan pencegahan kualitas udara yang semakin memburuk. Salah satu senjata pemerintah yang dapat digunakan yaitu melalui regulasi ataupun kebijakan. Dengan memperketat aturan mengenai prosedur ataupun segala hal yang berkaitan dengan penggunaan batubara dirasa akan mampu mengurangi beban masyarakat dalam menanggung kualitas udara yang semakin memburuk akibat penggunaan batubara. Memang pastilah India telah memiliki undang-undang yang berkaitan dengan sumber daya mineral tersebut, namun melihat 
kurangnya efektifitas yang ditimbulkan atas kemunculan undang-undang yang telah dikeluarkan menuntut pemerintah untuk bergerak aktif dalam melakukan penindakan tegas sebagai upaya tindak lanjutnya serta dengan memperketat aturan mengenai penggunaan batubara. Kualitas udara yang akan dihirup masyarakat India kedepannya sangat ditentukan dengan bagaimana upaya tegas yang dilakukan pemerintah serta bergantung pada kesadaran akan lingkungan dari masyarakat khususnya pihak yang berkecimpung dengan batubara.

\section{KESIMPULAN}

Perubahan yang terjadi pada sistem alami bumi yang sering dirasakan akhir-akhir ini merupakan dampak dari ketidakmampuan bumi dalam menopang kebutuhan manusia yang semakin tidak terbatas. Salah satu masalah besar yang muncul akibat ketidakmampuan bumi tersebut adalah kualitas udara yang semakin memburuk akibat kadar polutan yang tidak terkendali. Batubara merupakan salah satu penyebab terbesar dalam terciptanya polusi udara di India sehingga negara tersebut menduduki sebagai negara dengan tingkat polusi udara terparah didunia. Polusi udara di India disebabkan karena sangat masifnya kegiatan produksi dan konsumsi yang dilakukan oleh negara tersebut. Perlu adanya kebijakan yang lebih tegas dari pemerintah untuk menindak berbagai penyimpangan yang dilakukan beberapa oknum dalam penggunaan batubara. Selain penindakan tegas, perlu diperketat pula berbagai aturan mengenai persyaratan, prosedur ataupun segala hal terkait dengan penggunaan batubara yang segala aktifitasnya akan melepaskan berbagai zat polutan ke udara.

\section{DAFTAR PUSTAKA}

Alfisyahri, N., Karimi, S. \& Ridwan, E. 2020. Hubungan Kausalitas Konsumsi Energi Hydropower, Emisi Karbon Dioksida dan Pertumbuhan Ekonomi pada Negaranegara G20. Jurnal Ilmiah MEA (Manajemen, Ekonomi \& Akuntansi).

Bhave, P. P. \& Shrestha, R. 2020. Mercury Air Pollution from Coal Combustion in India and Its Control Measures. Global Challenges in Energy and Environment.

Cusworth, D. H. et al. 2018. Quantifying the influence of agricultural fires in northwest India on urban air pollution in Delhi, India. Environmental ResearchLetters.

Gupta, R., Somanathan, E. \& Dey, S. 2017. Global warming and local air pollution have reduced wheat yields in India. Climatic Change.

Jain, R., Upadhyaya, N., Sharma, R. \& Upadhyaya, R. 2019. Environmental Policies, Laws and Legislations in India. International Journal of Advanced Scientific Research and Management.

Kumar, S., Kaushik, G. \& Villarreal-Chiu, J. F. 2016. Scenario of organophosphate pollution and toxicity in India: A review. Environmental Science and Pollution Research.

Marianta, E. S. 2012. Upaya India Dalam Menangani Masalah Keamanan Energi (Energy Security) Pada Masa Pemerintahan Perdana Menteri Manmohan Singh Tahun 2004 - 2009. UPN "VETERAN" YOGYAKARTA. 
Mursyidin \& Warnida, H. 2016. Persepsi Masyarakat Terhadap Dampak Kesehatan Dari Aktivitas Penambangan Batubara Di Kampung Tasuk Kabupaten Berau. Jurnal Ilmiah Manuntung.

Nayak, T. \& Chowdhury, I. R. 2018. Health Damages from Air Pollution: Evidence from Opencast Coal Mining Region of Odisha, India. Ecology.

Palit, H. B., Poekoel, V. \& Patras, L. S. 2017. Simulasi Dan Pengontrolan Sistem Pembuangan Abu di PLTU 2 Sulawei Utara. Jurnal Teknik Elektro dan Komputer.

Purnomo, E. P. et al. 2019. Land ownership transformation before and after forest fires in Indonesian palm oil plantation areas. Jornal Of Land Use Science.

Purnomo, E. P. \& Suhendri. 2017. Penguatan Kelembagaan Dalam Pencegahan dan Pengendalian Kebakaran Hutan dan Lahan di Kabupaten Muaro Jambi Provinsi Jambi. Journal of Governance and Public Policy.

Rezqi, J. B. 2016. Kebijakan Korea Selatan Dalam Polusi Udara Lintas Batas Tiongkok. Jurnal of International Relations.

Ruhiat, F., Heryadi, D. \& Akim. 2019. Strategi NGO Lingkungan Dalam Menangani Polusi Udara di Jakarta (Greenpeace Indonesia). Andalas Journal of International Studies (AJIS).

Santoso, K. B., Hakim, L., Ningrum, E. R. \& Widyatmanti, W. 2018. STUDI TEMPORAL PERTUMBUHAN EKONOMI DAN POLUSI UDARA. STUDI KASUS: DKI JAKARTA, SEMARANG, DAN SURABAYA PADA TAHUN 2005-2015. Jurnal Meteorologi Klimatologi dan Geofisika .

Setiawan, A. A., Budianta, D., Suheryanto \& Priadi, D. P. 2018. Pollution due to Coal Mining Activity and its Impact on Environment. Sriwijaya Journal of Environment.

Sirsikar, S. \& Karemore, P. 2015. Design And Implementation of Real Time Web Based Geographic Polution Monitoring System. International Conference on Computation of Power, Energy, Information and Communication (ICCPEIC).

Suharsono, A., Sanchez, L., Garg, V. \& Gass, P. 2019. Tackling Coal-Driven Air Pollution in China and India.

Tandon, U. 2008. POPULATION GROWTH AND SUSTAINABLE DEVELOPMENT. Journal of the Indian Law Institute.

Yusad, Y. 2003. Polusi Udara Dikota-Kota Besar Dunia. Fakultas Kesehatan Masyarakat Uiversitas Sumatra Utara.

Anggito, A. \& Setiawan, J. 2018. Metodologi Penelitian Kualitatif. Sukabumi: CV. Jejak.

Sachs, J. D. 2015. The Age of Sustainable Development, New York: Columbia University Press.

Soni, R., 2007. ESTIMATION OF VEHICULAR POLUTION LOAD IN DELHI AND IT'S CONTROL STRATEGIES. Doctoral dissertation.

CNNIndonesia. 2019. India Geser China Jadi Kota dengan Polusi Terburuk, Jakarta: CNN Indonesia.

esdm.go.id. 2008. Hingga 2030, Permintaan Energi Dunia Meningkat 45\%. [Online] Available at: https://www.esdm.go.id/id/media-center/arsip-berita/hingga-2030permintaan-energi-dunia-meningkat-45-[Diakses 27 April 2020]. 
id.wikipedia.org, 2018. Daftar Negara Menurut Jumlah Penduduk. [Online]

Available at:

ttps://id.wikipedia.org/wiki/Daftar_negara_menurut_jumlah_penduduk

[Diakses 2020 April 25].

indexmundi.com, 2020. Coal Consumption by Country. [Online]

Available at:

https://www.indexmundi.com/energy/?product=coal\&graph=consumption\&display $=$ rank[Diakses 25 April 2020].

indexmundi.com, t.thn. IndexMundi Country Facts. [Online]

Available at: www.indexmundi.com [Diakses 25 April 2020].

republika.co.id, 2019. India, Negara dengan Kematian Tertinggi Akibat Polusi. [Online] Available at: republika.co.id/berita/gaya-hidup/info-sehat/19/12/19/q2qvtv328india-negara-dengan-kematian-tertinggi-akibat-polusi [Diakses 1 Mei 2020].

Widyaningrum, G. L., 2019. Penelitian: Polusi Udara Membunuh Lebih Banyak Orang Dibanding Rokok. [Online]

Available at: https://nationalgeographic.grid.id/read/131669410/penelitian-polusiudara-membunuh-lebih-banyak-orang-dibanding-rokok [Diakses 9 Juni 2020]. 